\title{
The Effect of Juice Clarity and Several Conditions Promoting Yeast Growth on Fermentation Rate, the Production of Aroma Components and Wine Quality
}

\author{
A. C. HOUTMAN and C.' S. DU PLESSIS, \\ Oenological \& Viticultural Research Institute, Private Bag X5026, Stellenbosch, 7600 \\ Special thanks are due to $\mathrm{Mr}$. $\mathrm{H}$. Pool for assistance in the making of the wines and performing gaschromatographic analyses on them.
}

\begin{abstract}
In cellar practice grape juice is preferably made as clear as possible, and fermentations take place under strictly anaerobic conditions. In the laboratory, however, the fermentation rate of EK-filtered and de-aerated juices was always so much slower than that of juices obtained by normal cellar routine that no dry wines could be prepared unless fermentation stimulating methods were applied. Apparently in most cellar fermentations sufficient amounts of oxygen and/or of yeast growth promoting steroids from the grapes are present to complete fermentation, but the exact amounts present are unknown. In practice problems with lagging fermentation could occur in cases where clarifying and de-aeration of juice were performed too rigorously.

Grape juice was clarified by diverse methods, and white wines were prepared from the juices under various conditions in order to study the effect of de-aeration, addition of settled juice with residual turbidity, micro-aeration and application of ergosterol suspensions on fermentation rate. EK-filtered juices were used to experiment with methods for reactivating lagging fermentation and also for investigating the effect of fermentation conditions on the production of wine volatiles. With the aid of the above-mentioned fermentation stimulating means the fermentation of EK-filtered juices could be completed within an acceptable period of time.

Steps to reactivate lagging fermentations should be taken as early as possible, although additions of settled juice were often successful, even when applied at a late stage during fermentation. Filtered juice from different cultivars and origins behaved in a markedly similar way with regard to fermentation and the production of volatile components. Filtration of juice caused partial loss of the cultivar character of the wine but wines from filtered juice with additions of ergosterol were nevertheless allotted the highest scores during organoleptic evaluation. The production of higher alcohols depends on the degree of juice turbidity and fermentation temperature. In clear filtered juice, however, the production of higher alcohols was independent of fermentation temperature. The formation of acetates of higher alcohols is greatly enhanced, by adding ergosterol to the filtered juice.
\end{abstract}

The purpose of this study was to find methods of directing aroma formation more reproducibly during fermentation and to produce a wider variety of wines.

Cellar experiments with the 1978 vintage proved that the best wines were obtained from highly clarified juices (Houtman, Marais \& du Plessis, 1980a). This favourable effect of stringent juice clarification on wine aroma has repeatedly been reported (Wucherpfennig \& Bretthauer, 1970; Singleton, Sieberhagen, de Wet \& van Wyk, 1975; Ribéreau-Gayon, Lafon-Lafourcade \& Bertrand, 1975; Bertrand, Marly-Brugerolle \& Sarre, 1978; Wenzel \& Dittrich, 1978; Williams, Ough \& Berg, 1978). The residual turbidity in juice after settling often contains substances which cause $\mathrm{H}_{2} \mathrm{~S}$-like off-odours in wine (Wenzel \& Dittrich, 1978; Houtman et al, 1980a). Wines from highly clarified juices are comparatively low in higher alcohol concentration, whereas the ester concentrations are reported to be enhanced (Crowell \& Guymon, 1963; Wucherpfennig \& Bretthauer, 1970; Ribéreau-Gayon et al, 1975; Bertrand et al, 1978; Groat \& Ough, 1978; Killian \& Ough, 1979). The resulting wine aroma is described as a light, pure, ester-like, fruity fermentation bouquet (Singleton et al, 1975; Williams et al, 1978; Ribéreau-Gayon, Sudraud \& Lafon-Lafourcade, 1978; Houtman et al, 1980a). The production of higher alcohols is also strongly dependent on fermentation temperature.
The higher concentrations were found after fermentation at $25^{\circ} \mathrm{C}$ rather than at $10^{\circ} \mathrm{C}$ (Crowell \& Guymon, 1963; Asmundo \& Zamorani, 1976).

The presence of oxygen in grape juice prior to fermentation, even oxidation of the juice, is not generally considered detrimental to wine quality. Processing of grapes and must under anaerobic conditions can even induce a too reductive atmosphere and thus cause $\mathrm{H}_{2} \mathrm{~S}$ formation (Perscheid \& Zürn, 1976; Müller-Späth, 1977; Müller-Späth, Loescher \& Schäfer, 1977). On the other hand, a too strong stimulation of yeast growth by aeration in the beginning of fermentation also causes highly reducing conditions, and thus $\mathrm{H}_{2} \mathrm{~S}$ formation, as soon as the oxygen has been consumed (Houtman et al, 1980a). Recently Dittrich (1978) and Vos \& Gray (1979) showed that $\mathrm{H}_{2} \mathrm{~S}$ production can be controlled effectively by a relatively high ammonium-nitrogen addition to juice.

The preference of South-African wine makers to make juices as clear as possible and to ferment under stricly anaerobic conditions seems to be well motivated. However, juice clarification may also result in a distinct loss of cultivar character, and wines tend to be too uniform. This loss of character is also reported by Williams et al, (1978). It has become quite evident, too, that excessive juice clarification is a cause of lagging fermentation (Wucherpfennig et al, 1970; Ribéreau-Gayon et al, 
1975; Groat \& Ough, 1978; Houtman et al, 1980a, b). Essential yeast-growth factors, such as ergosterol and other steroids, are removed from the juice by EKfiltration. Under absolute anaerobic conditions such filtered juice will never ferment to dryness. Paradoxically, this means that cellars having the most perfect devices run the largest risk of fermentation problems.

With regard to oxygen availability to proliferating yeast, a middle way should evidently be chosen. Quantitative data on aeration conditions for optimal wine quality are still lacking, especially in the case of highly clarified juices. In this connection recent observations on the function of ergosterol as a growth or survival factor for yeast are of great importance (Sapis-Domercq \& Peynaud, 1973; Larue, Lafon-Lafourcade \& RibéreauGayon, 1978; Lafon-Lafourcade \& Ribéreau-Gayon, 1979). In beer research, especially, the ergosterol need of proliferating yeast has been extensively investigated (David \& Kirsop, 1973; Aries \& Kirsop, 1977; Aries \& Kirsop, 1978; Kirsop, 1978).

The purpose of this investigation was:

- to confirm the 1978 cellar results with regard to juice clarity and wine quality;

- to test the effect of various fermentation stimulating measures on wine quality and the production of fermentation aroma components;

- to assess to what extent reproducible wine aromagrams could be obtained with juice from different grape cultivars.

\section{MATERIALS AND METHODS}

Juice: Cellar fermentations were performed with free-run juice from ripe and nearly ripe Chenin blanc grapes from two vineyards, viz. "Nietvoorbij" at Stellenbosch and "Nagenoeg" at Lynedoch. For the laboratory fermentations, juice of the cultivars Chenin blanc, Colombar and Cape Riesling were used.

Treatment of the juices: The following procedures were applied to obtain juice of six degrees of clarity:

1. After addition of $0,25 \mathrm{~g}$ bentonite/ $\ell$, free-run juice was allowed to settle under $\mathrm{CO}_{2}$ for 18 hours while cooling to $4{ }^{\circ} \mathrm{C}$ (S-juice).

2. Settling was performed in the same way as above after incubation of the juice with pectolytic enzymes for 3 hours at $20-25{ }^{\circ} \mathrm{C}$. (Ultrazym-100 $(2 \mathrm{~g} / \mathrm{h} \ell)$ or Spark-L ( $1 \mathrm{~g} / \mathrm{h} \ell)$ were used).

3. S-juice was filtered through a sterilizing EK-filter (EK-juice).

4. S-juice was filtered through a No. 3 cellulose-asbestos sheet. As a result of blocking of the filter by suspended juice particles, the filtrate became gradually cleaner in the course of filtration, and the first $10 \%$ was recycled.

5. S-juice centrifuged for 10 minutes at $1465 \mathrm{~g}$ (3000 $\mathrm{rpm})$.

6. S-juice centrifuged for 20 minutes at $10400 \mathrm{~g}$ (8000 $\mathrm{rpm})$.

The juices used for laboratory fermentations were stored under $\mathrm{CO}_{2}$ at $-14{ }^{\circ} \mathrm{C}$. Before use they were thawed and de-aerated for 10 minutes by means of a jet of nitrogen. Filling of the containers and flasks, inoculations and all other handlings of the must were performed in a closed system under $\mathrm{CO}_{2}$ gas.

These juices were subjected to various sub-treatments, viz:

(a) aeration of the must or the headspace by periodic injections of small volumes of air or by means of a continuous stream of $\mathrm{CO}_{2}$ mixed with various percentages of air applied with an Auto-Analyser pump (Fig. 1);

(b) ergosterol application: $45 \mathrm{mg}$ of ergosterol, dissolved in $5 \mathrm{~m} \ell$ boiling ethanol, were added hot to a litre of the juice and stirred by means of a $\mathrm{CO}_{2}$-stream;

(c) admixtures to EK-juice of S-juice or of the centrifuged precipitate from $\mathrm{S}$-juice;

(d) various other additions, such as bentonite $(0,5$ $\mathrm{g} / \ell),\left(\mathrm{NH}_{4}\right)_{2} \mathrm{HPO}_{4}(0,25-1,0 \mathrm{~g} / \ell)$ and Tween-80 $(300 \mathrm{mg} / \ell)$.

Fermentation: Most fermentations were carried out at 13 ${ }^{\circ} \mathrm{C}$ or $15^{\circ} \mathrm{C}$; the effect of juice turbidity on the production of higher alcohols was tested at $13{ }^{\circ} \mathrm{C}$ and $25^{\circ} \mathrm{C}$. Samples of $400 \mathrm{~m} \ell$ juice in $750 \mathrm{~cm}^{3}$ glass bottles were used in the laboratory. In the cellar $65 \ell$ lots were fermented in $90 \ell$ stainless steel containers. Bottles and containers were closed with plastic or glass fermentation locks.

Yeast: A pure culture of Saccharomyces cerevisiae (strain WE 14 of the OVRI) was used. Propagation of the yeast culture was carried out in sterilized juice at $13{ }^{\circ} \mathrm{C}$ for eight days. Unless otherwise stated, a 2,5\% inoculation of this yeast culture was used.

Determination of yeast mass and fermentation rate: Fermentation rate and yeast mass were defined and determined as described previously (Houtman et al, 1980a).

Gaschromatographic determination of aroma compounds: The method described by Marais \& Houtman (1979) was applied for the quantitative gaschromatographic determination of 14 volatile components in wine, namely the following eight esters, four alcohols and two acids: ethyl butyrate, ethyl hexanoate, ethyl octanoate, ethyl decanoate, ethyl acetate, i-amyl acetate, n-hexyl acetate, 2phenylethyl acetate, i-butanol, i-amyl alcohol, n-hexanol, 2-phenyl ethanol, hexanoic acid and octanoic acid.

Wine quality evaluation: A tasting panel of the OVRI evaluated the wines from the $65 \ell$ fermentations.

\section{RESULTS AND DISCUSSION}

The effect of various fermentation stimulating treatments on wine quality: The eighteen wines, prepared in the cellar from filtered juice, obtained significantly higher scores than those made by standard cellar procedure. The 1978 results with regard to juice clarity, de-aeration and bentonite treatment were thus confirmed. Especially, the six F-e-b wines (filter-ergosterol-bentonite treatment) obtained a good average score of $69 \%$ (Table 1). A more 


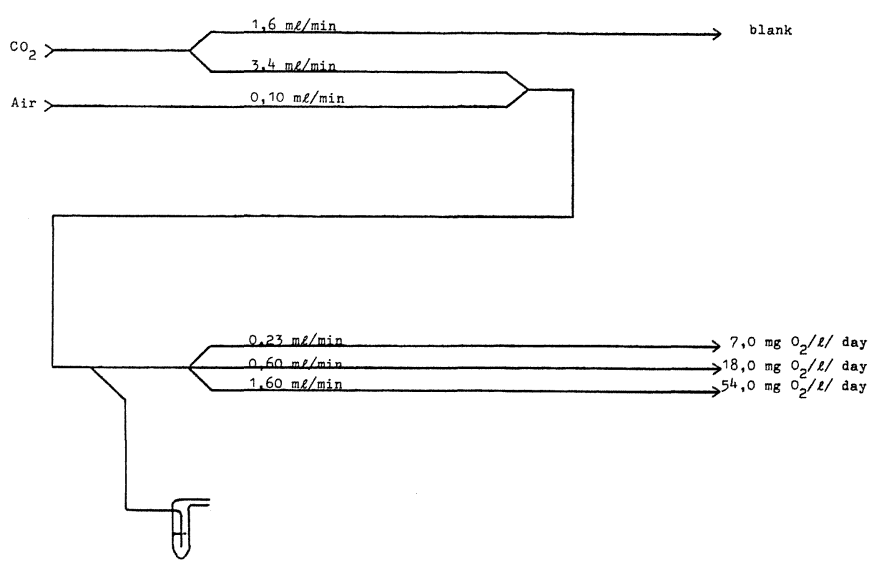

FIG. 1

An Auto-Analyser scheme for micro-aeration of $0,40 \ell$ samples of fermenting must.

TABLE 1

Sensory evaluation results of 30 wines made from settled and filtered juices under various fermentation conditions

\begin{tabular}{|c|c|c|c|c|c|c|}
\hline Fermentation code* & S & F-ae-b & F-m-b & F-e & F-e-b & D-value \\
\hline Juice purification & $\begin{array}{c}\text { Settled } \\
\text { under } \mathrm{CO}_{2}\end{array}$ & & \multicolumn{3}{|c|}{$\begin{array}{l}\text { Filtered through No. } 3 \\
\text { sheets; de-aerated with } \mathrm{N}_{2}\end{array}$} & \\
\hline Additions: bentonite $(\mathrm{mg} / \ell)$. & 0 & 500 & 500 & 0 & 500 & \\
\hline ergosterol $(\mathrm{mg} / \ell) \ldots \ldots \ldots \ldots \ldots \ldots \ldots$ & 0 & 0 & 0 & 35 & 35 & \\
\hline Inoculation (vol. \%) ....... & 2,5 & 2,5 & 10,0 & 2,5 & 2,5 & \\
\hline Wine score $(\%)$ & 51 & 59 & 60 & 64 & 69 & 4 \\
\hline
\end{tabular}

${ }^{*} \mathrm{~S}=$ settled, $\mathrm{F}=$ filtered, $\mathrm{m}=$ mass inoculation $(10 \%), \mathrm{b}=$ bentonite, ae $=$ headspace aerated before inoculation, $\mathrm{e}=$ ergosterol

detailed study concerning the effect of ergosterol on wine quality should, therefore, be undertaken. Most of these fermentations were slow, and the results seem to indicate that yeast produces better wines when fermenting under sub-optimal conditions. However, some of the ergosterolstimulated fermentations proceeded relatively fast and yet gave the best wines. These results with ergosterol suggest that it may be possible to separate the useful fermentation stimulating qualities of the suspended grape solids from their harmful properties, namely those enhancing the production of higher alcohols and causing malodours in wine.

Nevertheless, the fermentation of highly clarified and de-aerated juice is obviously hazardous. Not one of the filtered and de-aerated juices of the 1976-1980 vintages fermented dry unless fermentation stimulants were used. Similar problems were found with juices clarified by enzyme treatment or centrifuging (Table 2, Fig. 2).

Methods to regulate the fermentation time of clarified and de-aerated juice: Ergosterol addition: Although SouthAfrican legislation does not permit the use of ergosterol in cellar practice, the application of this vitamin-like product could not actually be described and condemned as "artificial", because ergosterol is a natural ingredient of grapes, occurring with other yeast-growth stimulating steroids in the wax layer on the grape berry (LafonLafourcade et al, 1979). During the crushing and pump- ing processes the wax layer can be partially dispersed in the juice in such a fine state that it may pass through a No. 3 filter. With the aid of EK-filters the active suspension can be completely removed (Fig. 2). The ability of the yeast cell to avail itself of this material is dependent to a large extent on the degree of dispersion. Crystalline ergosterol exerted no activity (Fig. 3). Artificial ergosterol suspensions had good fermentation promoting properties (Houtman et al, 1980a), especially in the presence of an emulsifying agent (Fig. 3), but on a mass/mass base they are by no means as active as the fine natural suspensions.

Aeration: In practice juice is not de-aerated, which explains the usually smooth running fermentations even in the case of enzyme-treated juice of high clarity. Oxygen enables the yeast to synthesize the required amount of ergosterol from squalene (Sapis-Domercq et al, 1973). Usually the oxygen concentration of fresh juice amounts to about $8 \mathrm{mg} / \ell$ and is sufficient to meet the requirement. According to Kirsop (1978) the yeast uses only $15 \%$ of the available oxygen for this synthesis. A surplus of air generally leads to off odours in wine. The $\mathrm{H}_{2} \mathrm{~S}$ odour, which was perceived in wines when the headspace above the juice was aerated before inoculation, can be ascribed to the metabolism of sulphur-containing amino acids by the actively proliferating yeast cells, and to the strongly reductive conditions in the must arising from yeast proliferation immediately after consumption of all available 


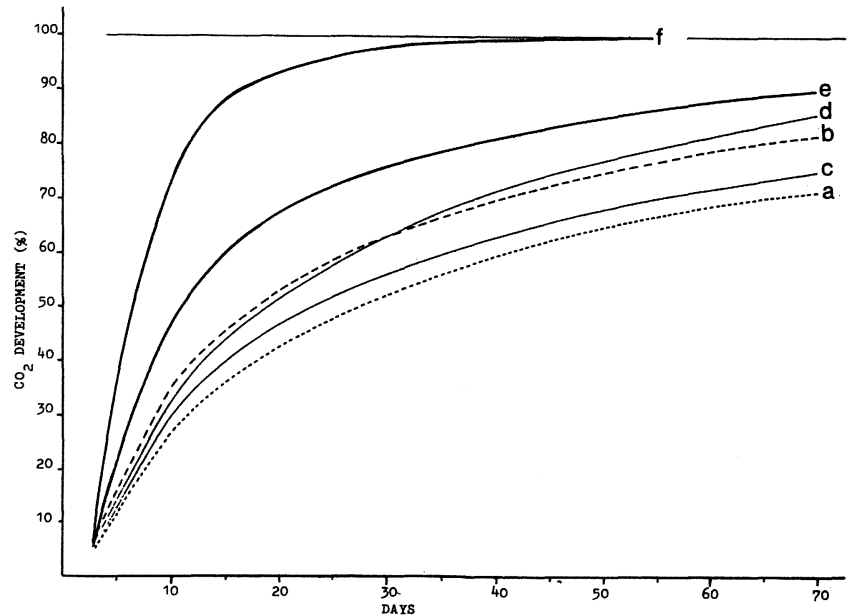

FIG. 2

Fermentation curves of de-aerated juices of six clarity grades.

a ------ EK-filtered juice.

b --- No. 3 filtered juice.

c - Centrifuged juice, $20 \mathrm{~min}$ at $10400 \times \mathrm{g}$.

$\mathrm{d}$ - Centrifuged juice, $10 \mathrm{~min}$ at $1465 \times \mathrm{g}$.

e — Enzyme treated and settled juice.

$\mathrm{f}-$ Bentonite treated and settled juice.

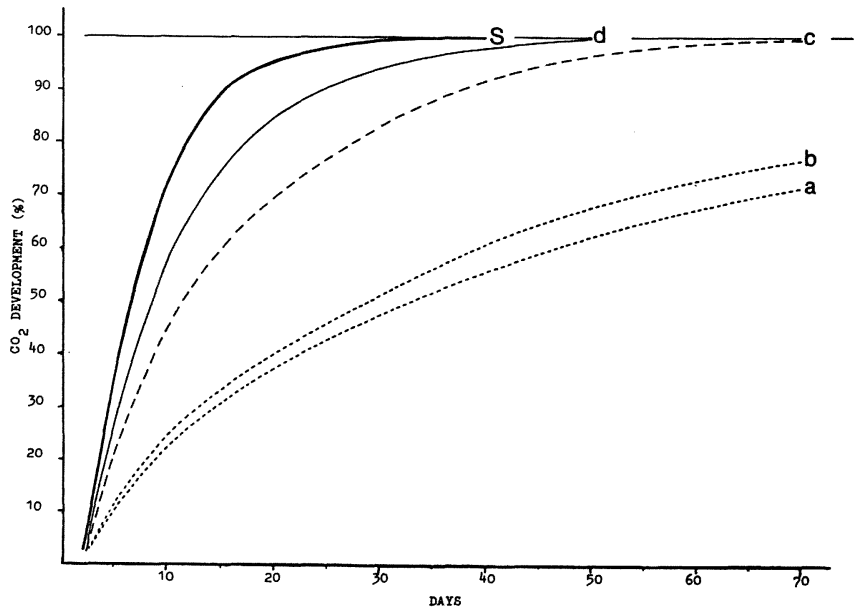

FIG. 3

The effect of ergosterol as such and in combination with Tween80 on the fermentation rate of EK-filtered and de-aerated grape juice (EK-juice).
a -...-. EK-juice.
b - EK-juice + crystalline ergosterol $(45 \mathrm{mg} / \ell)$.
c - - EK-juice + ergosterol $(45 \mathrm{mg} / \ell)$ in $5 \mathrm{ml}$ hot ethanol.
$\mathrm{d}$ - EK-juice + ergosterol $(45 \mathrm{mg} / \ell)+$ Tween-80 (300 $\mathrm{mg} / \ell$ ) in $5 \mathrm{ml}$ hot ethanol.
$\mathrm{S} \longrightarrow$ Settled and de-aerated juice.

TABLE 2

Frequency of lagging fermentations occurring with de-aerated juices in relation to the juice purification methods

\begin{tabular}{|c|c|c|c|c|}
\hline \multirow[b]{2}{*}{ Juice clearing method } & \multirow{2}{*}{$\begin{array}{l}\text { Number of } \\
\text { juice samples }\end{array}$} & \multirow{2}{*}{$\begin{array}{c}\text { Mean } \\
\text { fermentation } \\
\text { rate* } \\
\text { (\% day) }\end{array}$} & \multicolumn{2}{|c|}{$\begin{array}{l}\text { Frequency of wines } \\
\text { fermented dry within: }\end{array}$} \\
\hline & & & $\begin{array}{l}40 \text { days } \\
(\%)\end{array}$ & $\begin{array}{c}70 \text { days } \\
(\%)\end{array}$ \\
\hline Settling with bentonite $(25 \mathrm{~g} / \mathrm{h} \ell)$. & 40 & 9,1 & 85 & 100 \\
\hline Settling with enzyme treatment . & 9 & 4,5 & 22 & 67 \\
\hline Centrifuging $(10 \mathrm{~min}$ at $1465 \times \mathrm{g})$. & 5 & 3,8 & 20 & 40 \\
\hline 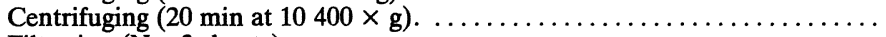 & 4 & 2,0 & 0 & 0 \\
\hline 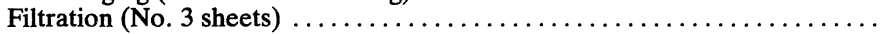 & 20 & 4,0 & 0 & 35 \\
\hline Filtration (EK-sheets) ............ & 42 & 1,9 & 0 & 0 \\
\hline Filtration (EK-sheets); headspace aerated before inoculation $\ldots \ldots \ldots \ldots \ldots$ & 30 & 7,1 & 33 & 97 \\
\hline
\end{tabular}

${ }^{*}$ Fermentation rate measured over the first $50 \%$ of sugar consumption.

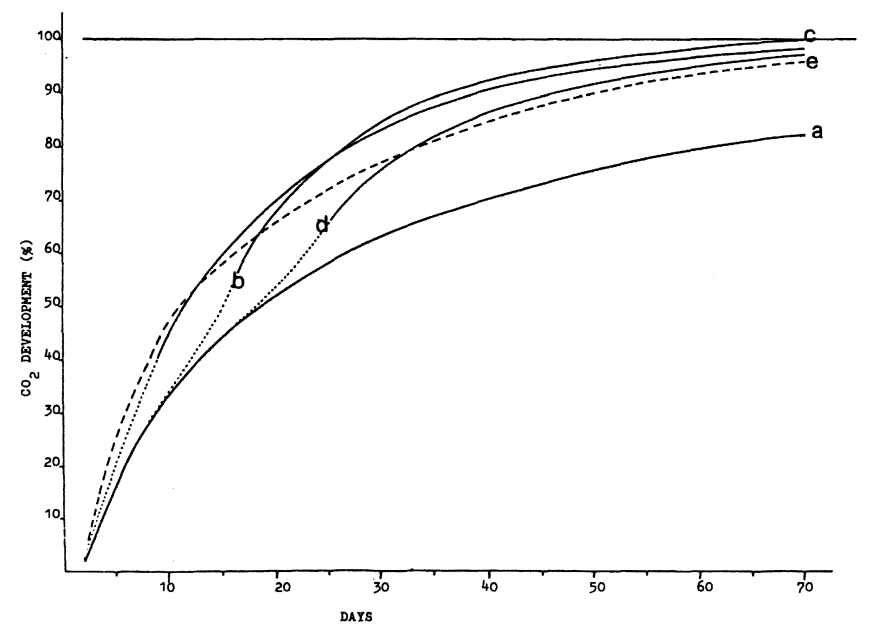

FIG. 4

Fermentation curves of EK-filtered and de-aerated juice with micro-aerations at various times.

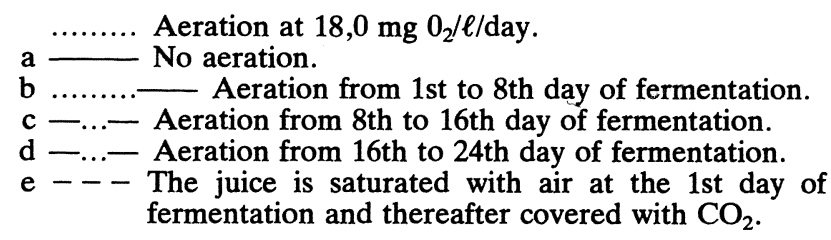

S. Afr. J. Enol. Vitic., Vol. 2. No. 2. 1981 
oxygen. According to Vos \& Gray (1979) $\mathrm{H}_{2} \mathrm{~S}$ malodours can be prevented by addition of di-ammoniumphosphate, thereby ensuring that the must is not deficient in nitrogen and that the amino acids will, therefore, not be degraded for nitrogen requirements.

In our experience an addition of $0,5 \mathrm{~g}\left(\mathrm{NH}_{4}\right)_{2} \mathrm{HPO}_{4} / \ell$ juice was not always adequate to prevent $\mathrm{H}_{2} \mathrm{~S}$-formation after an initial aeration of an inoculated must.

Another possibility is to de-aerate the clarified juice and to control the fermentation rate by means of small and regulated aerations. Thus the yeast can be kept in a condition of oxygen deficiency to prevent a too lively fermentation and an excessive amino acid degradation. The minimal required amount of oxygen and the best period and rate of application can thus be determinated experimentally on de-aerated EK-filtered juice. By means of an Auto-Analyser pump different amounts and ratios of air and $\mathrm{CO}_{2}$ can continuously or intermittently be administered to the must. Thus fermentation can be lead along a variety of rate-curves, some of which are presented in Fig. 4.

Suspended grape material; dispersion grade: The frequency of the occurrence of lagging fermentation in laboratory experiments with juices which were cleared in different ways, are given in Table 2. Settled grape juices of various cultivars and origins may behave quite differently with regard to fermentation rate and to the time required to complete fermentation (Table 3). However, the EKfiltrates of such juices behaved more or less identically, also in the case of small additions of one settled juice sample (Fig. 5). This emphasizes the fundamental differences between fermentation behaviour of settled and clear filtered juices. The fermentation behaviour of the enzymatically cleared and settled juice, as it is commonly used in cellars, lies somewhere in between. Experimental results with these undefined media are often difficult or impossible to reproduce. The difference in fermentation behaviour of various juices seems to be mainly the result of differences in the small amount of residual turbidity remaining in the juice after settling. The highest activity of the yeast growth stimulating steroid fraction was found in the Riesling sample. The smooth fermentation of No. 3-filtered Riesling juice, in contrast to its EK-filtrate, indicated that in this case a relatively large part of the steroids was so finely dispersed that they could pass the No. 3 filter. It stands to reason that the yeast growth promoting factor in this form will be best available to the yeast. There are strong indications that the degree of dispersion of this "factor" in grape juice is of considerable importance for its availability to the yeast. For example, an addition of settled Chenin blanc juice to EK-filtered juice enhanced the fermentation rate, whereas the centrifuged precipitate from the settled juice did not (Fig. 6). Accordingly, an addition of ergosterol to EK-filtered juice has a more pronounced fermentation promoting effect when added together with an emulsifier such as Tween-80 (Fig. 3). It is, therefore, of major importance to acquire more knowledge of the natural emulsifying agents in grape juice.

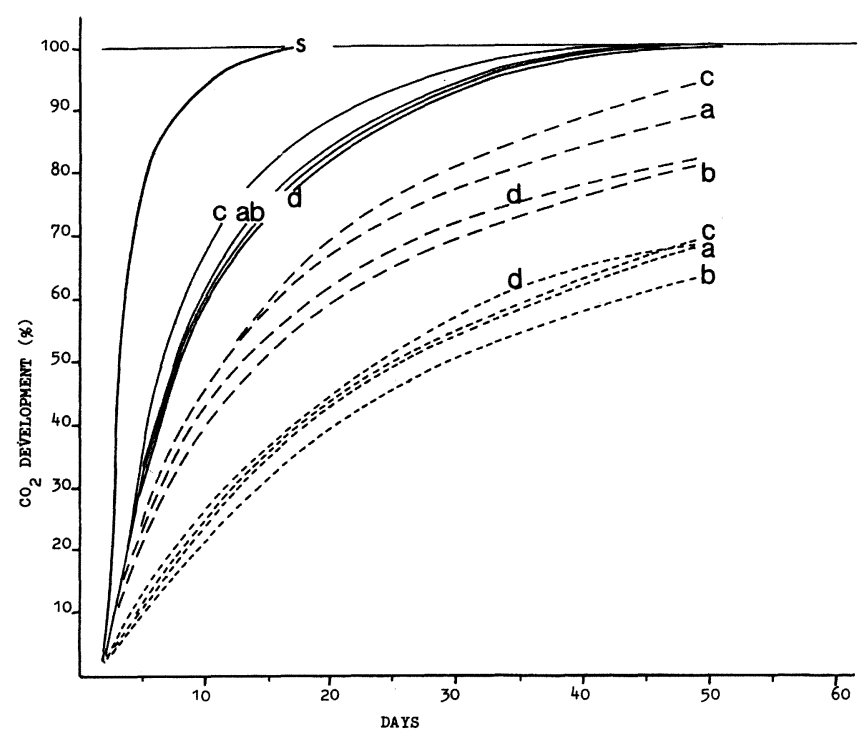

Fig. 5

Fermentation curves of four EK-filtered juices with various additions of settled juice.

a Chenin blanc $\left(19,2^{\circ} \mathrm{B}\right)$.

b Chenin blanc $\left(21,1^{\circ} \mathbf{B}\right)$.

c Cape Riesling.

d Colombar. De-aerated EK-filtrates.

- S - De-aerated settled juice (Cape Riesling).

- - - De-aerated EK-filtrates + 5\% S.

De-aerated EK-filtrates $+15 \%$ S.

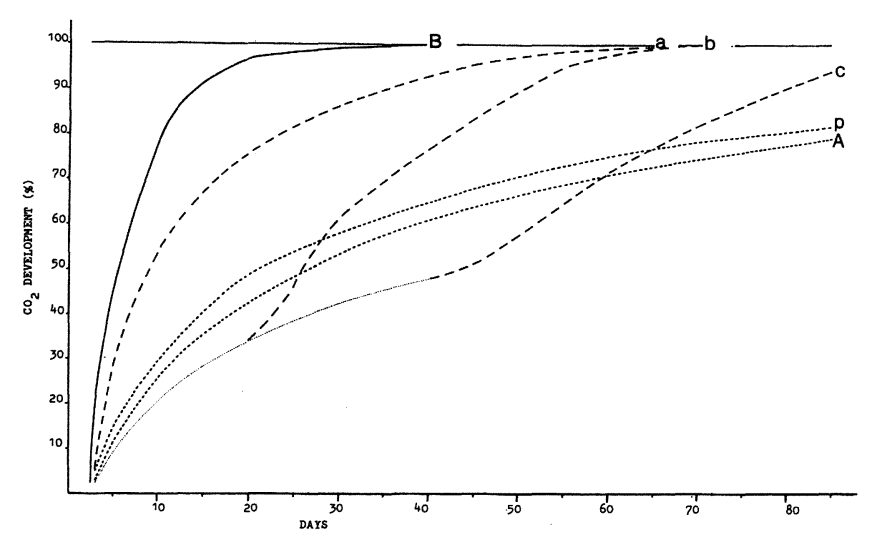

FIG. 6

The fermentation rate of EK-filtered and de-aerated grape juice with 25 vol. $\%$ additions of de-aerated settled juice at three points of time.

\footnotetext{
A -.---- EK-filtered and de-aerated juice.

B - Settled and de-aerated juice.

a $---80 \%$ A $+20 \%$ B; admixture before inoculation.

b $---80 \% \mathrm{~A}+20 \% \mathrm{~B}$; admixture at the 20 th day.

c - - $-80 \% A+20 \% \mathrm{~B}$; admixture at the 45th day.

p ------ Juice $A$ with an addition of the centrifuged precipitate from $1 / 4$ volume of juice $B$.
} 
TABLE 3

Fermentation rate of four settled and de-aerated grape juices of different cultivar and origin

\begin{tabular}{|c|c|c|}
\hline Grape juice & $\begin{array}{l}\text { Rate during the } \\
\text { first half of } \\
\text { fermentation } \\
\text { (\% day) }\end{array}$ & $\begin{array}{c}\text { Time required } \\
\text { for complete } \\
\text { fermentation } \\
\text { (days) }\end{array}$ \\
\hline Chenin blanc (Stellenbosch). & 10,0 & 40 \\
\hline Chenin blanc (Lynedoch) ... & 7,1 & 24 \\
\hline Cape Riesling ........... & 13,0 & 14 \\
\hline Colombar ........... & 6,0 & 48 \\
\hline
\end{tabular}

"Mass inoculation" and addition of ammonium-nitrogen: The fermentation rate of EK-filtered and de-aerated juices was increased by massive inoculations (10\%) as well as by the addition of di-ammonium phosphate (Fig. 7). In these cases the treatments did not suffice to effect complete fermentation, but with No. 3 filtrates and juices which were less drastically purified and de-aerated, the combination of large inoculum volumes and the addition of nitrogen were in most cases sufficient to allow the fermentation to continue to completion. In practice this combination can be useful in shortening fermentation time.

Procedures to revive lagging fermentation of clear juice: Reviving of lagging fermentation by means of racking is a hazardous operation with regard to wine quality because of the possibility of oxidation. The later a lagging fermentation is treated, the more difficult it becomes to reactivate the yeast. It is better, therefore, to arrange conditions beforehand so that a completion of the fermentation can be expected. Four reactivating agents were studied, namely ergosterol, fresh yeast inoculation, aeration and addition of settled juice.

Ergosterol addition: When ergosterol was added to a fermenting clear juice some days after inoculation, it did not enhance fermentation (Houtman et al, 1980a). However, a combination of ergosterol $(45 \mathrm{mg} / \ell)$ and Tween-80 (300 mg/ $\ell$ ) speeded up lagging fermentations of clear juices, even on the 7th day after inoculation (Fig. 8 ). Of course, Tween- 80 cannot be applied in practical oenology. The principle may be applied in future cellar practice only if preparations of natural grape emulsifying agents should become available, and if the law should allow them to be used.

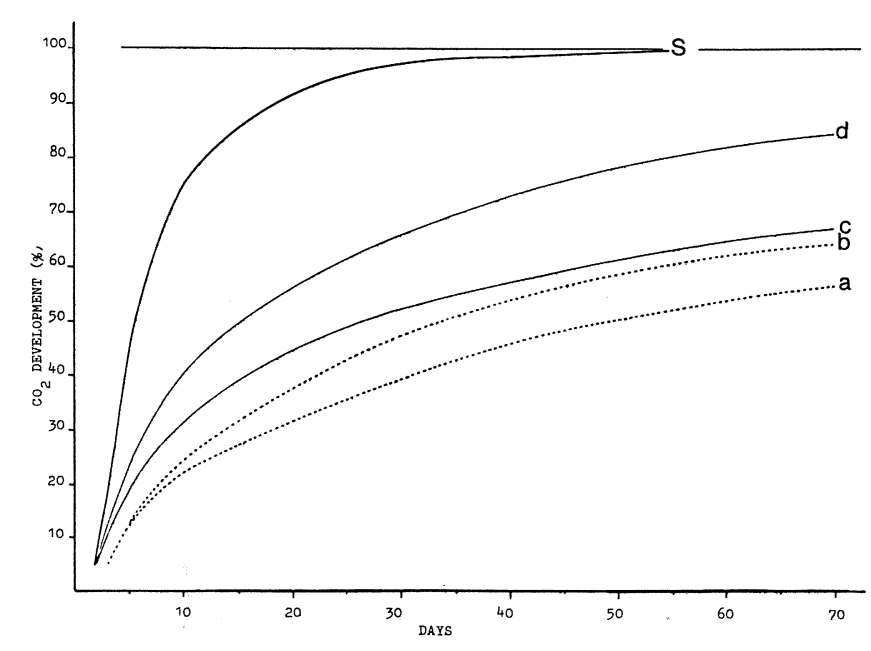

Fig. 7

The effect of inoculation concentration and addition of diammonium phosphate on the fermentation rate of EK-filtered and de-aerated grape juice (EK-juice).

a -...-. EK-juice; inoculation concentration 2,5\%.

b ..... EK-juice + $\left(\mathrm{NH}_{4}\right)_{2} \mathrm{HPO}_{4}(1,0 \mathrm{~g} / \ell)$; inoculation concentration $2,5 \%$.

c - EK-juice; inoculation concentration $10,0 \%$.

$\mathrm{d}-\mathrm{EK}$-juice $+\left(\mathrm{NH}_{4}\right)_{2} \mathrm{HPO}_{4}(1,0 \mathrm{~g} / \ell)$; inoculation concentration $10,0 \%$.

$\mathrm{S} \longrightarrow$ Settled juice; inoculation concentration $2,5 \%$.

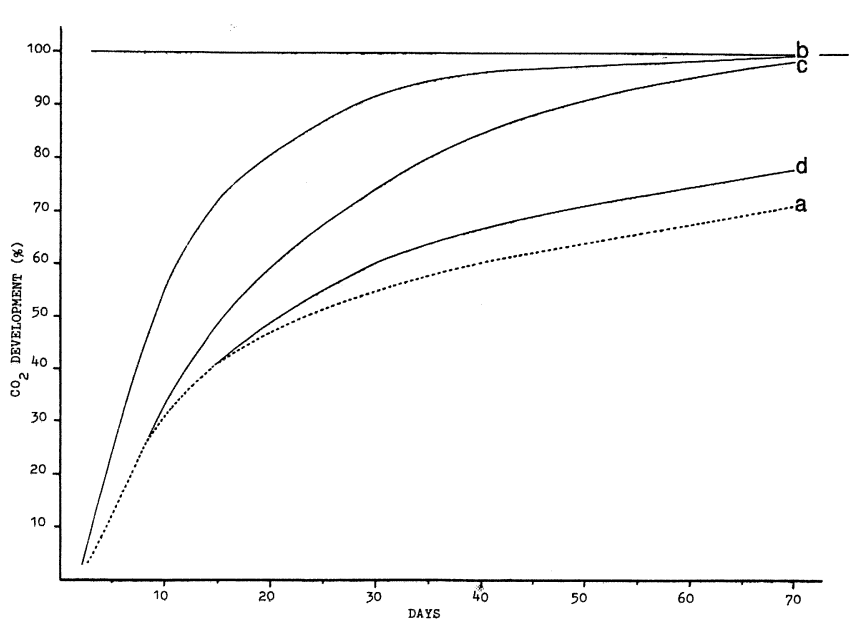

Fig. 8

Reactivation of lagging fermentations of EK-filtered and deaerated juice with ergosterol and Tween- 80 at various times after inoculation.

$\mathrm{a}-\mathrm{B}$ Ank.
$\mathrm{b}-\mathrm{Addition}$ of ergosterol $(45 \mathrm{mg} / \ell)$ and Tween-80 (300
$\mathrm{mg} / \ell)$ before inoculation.
$\mathrm{c}-$ Additions as b but at the 7 th day of fermentation.
$\mathrm{d}-$ Additions as b but at the 13 th day of fermentation. 
Fresh yeast inoculation: Inoculation of lagging fermentations with fresh yeast was not successful in reviving fermentation.

Aeration: Racking is the classic method for the revival of lagging fermentation. It is in fact based on aeration, which may cause oxidation and thus be detrimental to wine quality. In our experiments a partial aeration of the headspace (even a very small leakage of air through the stopper of the vessel) was sufficient to carry lagging fermentations of highly clarified juices to completion. Experiments with quantitatively controlled microaerations at different stages of lagging fermentation have confirmed this observation (Fig. 4). However, in most cases oxidation symptoms were observed and wine scores decreased. As in the case of early aeration, the principle of quantitatively regulated micro-aerations during fermentation should be investigated thoroughly. At present it is not advisable to aerate after the lowest point of the redox potential has been reached.

Addition of settled juice: At present the safest way to overcome lagging fermentation of highly clarified juice appears to be an addition of about $25 \mathrm{vol} . \%$ of a settled juice (Fig. 6). However, from the foregoing it is clear that all settled juices do not necessarily have the same yeast-growth stimulating capacity.

Factors affecting the production of aroma components during fermentation: Gaschromatograms of wines may be used to gain an impression of the degree of reproducibility of fermentation results and also to compare grape cultivars, juice preparation methods and fermentation conditions with regard to the formation of fermentation aroma components.

From the wine aromagrams it appears that, even with the exclusion of ethanol and acetic acid, far more than $95 \%$ of the wine volatiles is formed by the yeast on a mass basis. More than $90 \%$ of the fermentation aroma complex is made up of some fourteen components. The major components of the fermentation volatiles belong to four chemical classes, viz. higher alcohols, acetates of these alcohols, fatty acids and the ethyl esters of these acids. The correlation between must sugar content and the concentrations of ethyl octanoate and ethyl decanoate was shown previously (Houtman et al, 1980a,b). The range of concentrations of these ethyl esters is rather limited.

Notably larger variations were observed in the concentrations of higher alcohols and their acetates in wines in relation to fermentation conditions. Concentrations of i-amyl acetate, for example, varied between 0,8 and 15 $\mathrm{mg} / \ell$. These alcohols and acetates are, therefore, much more sensitive parameters for measuring the reproducibility of fermentation than the ethyl esters.

In this respect it is noteworthy that $\mathrm{i}$-amyl acetate also proved to be a sensitive parameter with regard to statistical classification of white wines by origin (Marais, Van Rooyen \& du Plessis, 1981). In Table 4 the results of gaschromatographic analyses of the cellar wines mentioned in Table 1 are recorded and may be summarized as follows:

Filtration: All wines from filtered juices were nearly identical with regard to their ethyl ester and higher alcohol concentrations.
Filtration and ergosterol addition: All fourteen cellar wines from filtered juice with ergosterol addition were equally high in acetate concentrations, significantly higher (about threefold) than the other series. This effect was similar for i-amyl acetate, 2-phenyl ethyl acetate and n-hexyl acetate and also visible with the ethyl acetate concentrations. Apparently the generation of "activated acetic acid" (the Co-enzyme derivate of acetic acid; $\mathrm{CH}_{3-}$ CO-S-CoA) is enhanced by ergosterol (Nordström, 1963; Nordström, 1966).

Settled and filtered juices; fermentation temperature: The wines made from settled juices were higher in higher alcohol concentrations than wines from filtered juices. Table 5 shows that of all the volatiles measured in this study, the concentrations of the higher alcohols are affected most by the combination of the variables juice turbidity and fermentation temperature. The concentration of the higher alcohols in the wines from EK-filtered juice was remarkably low and independent of fermentation temperature. The concentrations of higher alcohols in wines from settled juices, fermented at $13{ }^{\circ} \mathrm{C}$, were roughly double, compared with those of the abovementioned wines. After fermentation at $25{ }^{\circ} \mathrm{C}$ the concentrations were nearly quadrupled. Apparently, unacceptable high values of the higher alcohol concentrations in wines can be attributed entirely to the presence of grape solids in the juice, especially in the case of higher fermentation temperatures. In this respect i-butanol was the most sensitive alcohol.

Filtration and aeration: Micro-aerations at various stages of fermentation did not affect the concentration of most of the volatile components in the wines. An aeration of $20 \mathrm{mg} 0_{2} / \ell / \mathrm{day}$, from the 7 th to 14 th day of fermentation however, often resulted in a rise of ethyl dec-9-enoate concentration from zero up to about $0,2 \mathrm{mg} / \ell$; the ethyl decanoate concentration was correspondingly decreased as a result of this oxidation.

Similarity of the fermentation-aroma composition of wines from different vineyards: Chenin blanc wines were made from grapes from each of two vineyards differing considerably in situation, soil type and fertilizer application. Both groups were handled identically with regard to filtration of the juice, de-aeration, yeast inoculum and fermentation stimulation by air and by ergosterol. Between comparable wines of both groups no difference in the concentrations of any but two of the volatiles was found, namely in $\mathrm{n}$-hexanol and its acetate, which appeared to be highly origin-specific (Table 6).

Similarity of wine aromagrams of three cultivars: Duplicate wines made from the same juice and fermented with the same yeast under identical conditions usually yielded similar aromagrams. Under such conditions even wines from filtered juices of different cultivars often gave remarkably similar aromagrams (Table 7, column I, especially Chenin blanc and C. Riesling). In wines from settled juices usually more substantial differences in aroma composition were observed, especially with regard to the concentrations of acetates and higher alcohols (Table 7, column II).

Cellar and laboratory fermentations: In all cellar and laboratory fermentations, carried out with the same juices under apparently comparable conditions, the con- 
TABLE 4

The effect of juice purification and different fermentation conditions on the content of volatiles in the wines

\begin{tabular}{|c|c|c|c|c|c|c|c|c|}
\hline \multicolumn{2}{|c|}{ Fermentation code ${ }^{*}$} & $\mathrm{~S}$ & F-ae-b & F-m-b & F-e-b & F-e & & \\
\hline Fermer & & \multicolumn{5}{|c|}{ Cellar scale $(65 \ell)$} & $\begin{array}{c}\text { Laboratory } \\
\text { scale } \\
(0,4 \ell)\end{array}$ & $\begin{array}{c}\text { D-values } \\
(5 \%)\end{array}$ \\
\hline \multicolumn{2}{|c|}{ Volatile components } & \multicolumn{6}{|c|}{ Concentration of volatile components $(\mathrm{mg} / \ell)$} & \\
\hline Ethyl butyrate & $\left(\mathrm{C}_{4} \mathrm{E}\right)$ & 0,39 & 0,48 & 0,47 & 0,52 & 0,49 & 0,37 & 0,10 \\
\hline Ethyl hexanoate & $\left(\mathrm{C}_{6} \mathrm{E}\right)$ & 0,77 & 0,99 & 1,02 & 1,33 & 1,18 & 0,77 & 0,11 \\
\hline Ethyl octanoate & $\left(\mathrm{C}_{8} \mathrm{E}\right)$ & 1,15 & 1,40 & 1,45 & 1,45 & 1,45 & 0,85 & 0,15 \\
\hline Ethyl decanoate & $\left(\mathrm{C}_{10} \mathrm{E}\right)$ & 0,48 & 0,55 & 0,57 & 0,59 & 0,58 & 0,37 & 0,07 \\
\hline Ethyl acetate & (EtA) & 33 & 43 & 40 & 60 & 62 & 52 & 13 \\
\hline i-Amyl acetate & $(\mathrm{AmA})$ & 1,95 & 2,80 & 3,20 & 6,40 & 6,05 & 2,80 & 0,70 \\
\hline n-Hexyl acetate & $(\mathrm{HxA})$ & 0,09 & 0,19 & 0,21 & 0,32 & 0,30 & 0,11 & 0,05 \\
\hline 2-Phenylethyl acetate & (PEA) & 0,04 & 0,07 & 0,11 & 0,25 & 0,25 & 0,12 & 0,05 \\
\hline i-Butanol & $(\mathrm{BuOH})$ & 36 & 26 & 26 & 23 & 23 & 16 & 4 \\
\hline i-Amyl alcohol & $(\mathrm{AmOH})$ & 160 & 125 & 125 & 120 & 120 & 71 & 15 \\
\hline n-Hexanol & $(\mathrm{HxOH})$ & 1,10 & 0,85 & 1,00 & 0,73 & 0,70 & 0,44 & 0,25 \\
\hline 2-Phenyl ethanol & $(\mathrm{PEOH})$ & 13,0 & 8,3 & 9,5 & 8,2 & 9,2 & 5,7 & NS \\
\hline
\end{tabular}

${ }^{*}$ Compare Table 1.

TABLE 5

The combined effects of juice clarity and fermentation temperature on the concentration of volatiles in wines

\begin{tabular}{|c|c|c|c|c|}
\hline \multirow{2}{*}{ 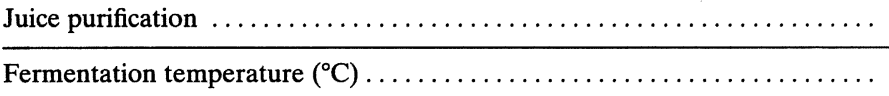 } & \multicolumn{2}{|c|}{ EK-filtration } & \multicolumn{2}{|c|}{ Settling with bentonite } \\
\hline & 15 & 25 & 15 & 25 \\
\hline 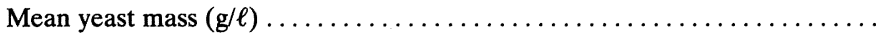 & 3,5 & 2,2 & 8,2 & 7,6 \\
\hline Volatiles* & \multicolumn{4}{|c|}{ Mean concentration of volatile wine components $(\mathrm{mg} / \ell)$} \\
\hline 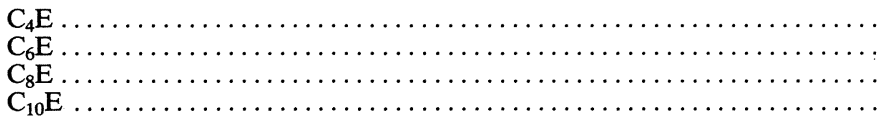 & $\begin{array}{l}0,27 \\
0,96 \\
0,86 \\
0,34\end{array}$ & $\begin{array}{l}0,19 \\
0,52 \\
0,70 \\
0,41\end{array}$ & $\begin{array}{l}0,37 \\
0,72 \\
1,07 \\
0,41\end{array}$ & $\begin{array}{l}0,20 \\
0,34 \\
0,64 \\
0,52\end{array}$ \\
\hline 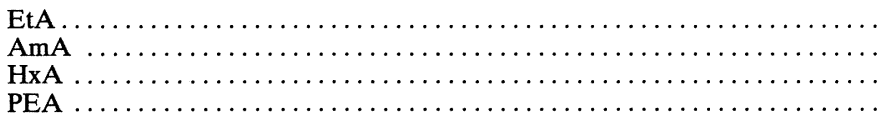 & $\begin{array}{r}23 \\
1,05 \\
0,08 \\
0,03\end{array}$ & $\begin{array}{r}31 \\
0,60 \\
0,05 \\
0,04\end{array}$ & $\begin{array}{l}28 \\
1,60 \\
0,03 \\
0,05\end{array}$ & $\begin{array}{r}21 \\
1,65 \\
0,03 \\
0,10\end{array}$ \\
\hline $\begin{array}{l}\mathrm{BuOH} \\
\mathrm{AmOH} \\
\mathrm{HxOH} \\
\mathrm{PEOH}\end{array}$ & $\begin{array}{l}16,5 \\
71 \\
0,57 \\
5,2\end{array}$ & $\begin{array}{l}21,5 \\
62 \\
0,63 \\
6,4\end{array}$ & $\begin{array}{l}39 \\
122 \\
0,81 \\
8,2\end{array}$ & $\begin{array}{l}115 \\
242 \\
0,70 \\
19,2\end{array}$ \\
\hline $\begin{array}{l}\mathrm{C}_{6} \mathrm{ac} \\
\mathrm{C}_{8} \mathrm{ac} \\
\ldots\end{array}$ & $\begin{array}{l}5,3 \\
6,7\end{array}$ & $\begin{array}{l}3,4 \\
4,8\end{array}$ & $\begin{array}{l}4,4 \\
6,8\end{array}$ & $\begin{array}{l}2,3 \\
5,9\end{array}$ \\
\hline
\end{tabular}

${ }^{*}$ Abbreviations as in Table $4 ; \mathrm{C}_{6} \mathrm{ac}=$ hexanoic acid, $\mathrm{C}_{8} \mathrm{ac}=$ octanoic acid.

TABLE 6

The concentration of volatiles in wines from the vineyards of "Nietvoorbij" and "Nagenoeg"

\begin{tabular}{|c|c|c|c|}
\hline Origin & $\begin{array}{l}\text { Nietvoorbij } \\
\text { Stellenbosch }\end{array}$ & $\begin{array}{l}\text { Nagenoeg } \\
\text { Lynedoch }\end{array}$ & \multirow{2}{*}{$\begin{array}{c}\text { Significance } \\
\text { of } \\
\text { differences }\end{array}$} \\
\hline $\begin{array}{l}\text { Volatile } \\
\text { components* }\end{array}$ & \multicolumn{2}{|c|}{$\begin{array}{l}\text { Mean concentration of volatiles } \\
\qquad(\mathrm{mg} / \ell)\end{array}$} & \\
\hline $\begin{array}{l}\mathrm{C}_{4} \mathrm{E} \ldots \ldots \ldots \\
\mathrm{C}_{6} \mathrm{E} \ldots \ldots \ldots \ldots \\
\mathrm{C}_{8} \mathrm{E} \ldots \ldots \ldots \ldots \\
\mathrm{C}_{10} \mathrm{E} \ldots \ldots \ldots \ldots\end{array}$ & $\begin{array}{l}0,50 \\
1,15 \\
1,38 \\
0,58\end{array}$ & $\begin{array}{l}0,48 \\
1,12 \\
1,46 \\
0,57\end{array}$ & $\begin{array}{l}\text { NS } \\
\text { NS } \\
\text { NS } \\
\text { NS }\end{array}$ \\
\hline $\begin{array}{l}\operatorname{EtA} \ldots \ldots \\
\operatorname{AmA} \ldots \ldots \\
\text { HxA } \ldots \ldots \\
\text { PEA } \ldots \ldots \cdots\end{array}$ & $\begin{array}{l}55 \\
4,5 \\
0,21 \\
0,18\end{array}$ & $\begin{array}{l}49 \\
4,4 \\
0,27 \\
0,16\end{array}$ & $\begin{array}{l}\text { NS } \\
\text { NS } \\
* * \\
\text { NS }\end{array}$ \\
\hline 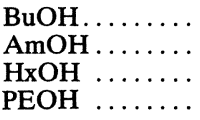 & $\begin{array}{c}24 \\
128 \\
0,62 \\
9,0\end{array}$ & $\begin{array}{c}24,5 \\
118 \\
0,91 \\
8,2\end{array}$ & $\begin{array}{l}\text { NS } \\
\text { NS } \\
* * \\
\text { NS }\end{array}$ \\
\hline
\end{tabular}

*Abbreviations as in Table 4.

**Highly significant at $\mathrm{P} \leqslant 0,01$. NS Not significant.

centrations of volatiles in the cellar wines were considerably higher than in the laboratory wines (Tables 4 and 8). This is an indication of the existence of another important factor, which is probably connected to differences in the propagation of the inoculum in the cellar and laboratory. This possible effect of inoculum conditions should be investigated further.

Amino-nitrogen addition to filtered juices: By addition of di-ammonium phosphate the amino-nitrogen content of juices was brought to two levels, viz. 105 and $300 \mathrm{mg} \mathrm{N} / \ell$ (Table 9). The addition of the ammonium salt to the clear juice had no significant effect on the concentration of esters. The concentrations of i-amyl alcohol and 2-phenyl ethanol were significantly decreased, which is remarkable because wines made from clear juice are already low in higher alcohol concentration. 
TABLE 7

Aroma composition of Chenin blanc (Ch.bl), Colombar (C) and Cape Riesling (C.R.) wines from the de-aerated filtered juices in comparison with that from the de-aerated settled juices

\begin{tabular}{|c|c|c|c|c|c|c|}
\hline $\begin{array}{l}\text { Column } \ldots \ldots \ldots \ldots \ldots \ldots \ldots \ldots \ldots \ldots \ldots \\
\text { Juice clarification } \\
\text { Cultivar } \ldots \ldots \ldots \ldots \ldots \ldots \ldots \ldots \ldots\end{array}$ & Ch.bl & $\begin{array}{l}\text { I } \\
\text { Filtration }\end{array}$ & C.R. & Ch.bl & $\underset{\text { Settling }}{\text { II }}$ & C.R. \\
\hline 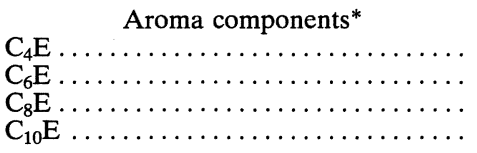 & $\begin{array}{l}0,30 \\
0,69 \\
0,92 \\
0,42\end{array}$ & $\begin{array}{l}0,29 \\
0,65 \\
0,77 \\
0,32\end{array}$ & $\begin{array}{c}\text { entratio } \\
0,28 \\
0,69 \\
0,93 \\
0,40\end{array}$ & $\begin{array}{r}\text { vines }(\mathrm{m} \\
0,51 \\
0,87 \\
1,54 \\
0,61\end{array}$ & $\begin{array}{l}0,49 \\
1,13 \\
1,45 \\
0,54\end{array}$ & $\begin{array}{l}0,57 \\
0,83 \\
1,34 \\
0,47\end{array}$ \\
\hline 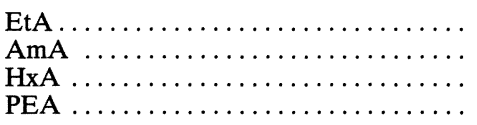 & $\begin{array}{l}30 \\
1,2 \\
0,07 \\
0,02\end{array}$ & $\begin{array}{l}26 \\
0,8 \\
0,05 \\
0,02\end{array}$ & $\begin{array}{l}27 \\
1,0 \\
0,06 \\
0,02\end{array}$ & $\begin{array}{l}39 \\
3,7 \\
0,14 \\
0,09\end{array}$ & $\begin{array}{l}33 \\
4,6 \\
0,23 \\
0,15\end{array}$ & $\begin{array}{l}45 \\
3,8 \\
0,07 \\
0,09\end{array}$ \\
\hline 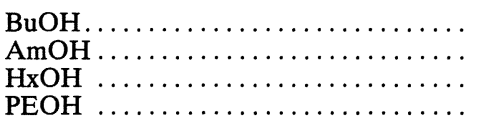 & $\begin{array}{l}12 \\
78 \\
0,52 \\
5,4\end{array}$ & $\begin{array}{l}10 \\
60 \\
0,44 \\
3,8\end{array}$ & $\begin{array}{l}11 \\
70 \\
0,51 \\
5,0\end{array}$ & $\begin{array}{c}24 \\
157 \\
0,83 \\
11,0\end{array}$ & $\begin{array}{l}12 \\
70 \\
0,70 \\
6,0\end{array}$ & $\begin{array}{c}24 \\
130 \\
0,95 \\
7,5\end{array}$ \\
\hline $\begin{array}{l}\mathrm{C}_{6} \mathrm{ac} \ldots \ldots \ldots \ldots \ldots \ldots \ldots \ldots \ldots \ldots \ldots \ldots \ldots \ldots \ldots \ldots \ldots \ldots \ldots \ldots \ldots \\
\mathrm{C}_{8} \mathrm{ac} \ldots \ldots \ldots \ldots \ldots \ldots \ldots \ldots\end{array}$ & $\begin{array}{l}4,7 \\
4,8\end{array}$ & $\begin{array}{l}5,6 \\
4,6\end{array}$ & $\begin{array}{l}5,1 \\
5,1\end{array}$ & $\begin{array}{l}5,5 \\
7,3\end{array}$ & $\begin{array}{l}6,4 \\
8,0\end{array}$ & $\begin{array}{l}7,2 \\
7,5\end{array}$ \\
\hline
\end{tabular}

${ }^{*}$ Abbrevations as in Tables 4 and 5 .

TABLE 8

Comparison of the concentrations of volatiles in cellar and laboratory wines $(1,2)$

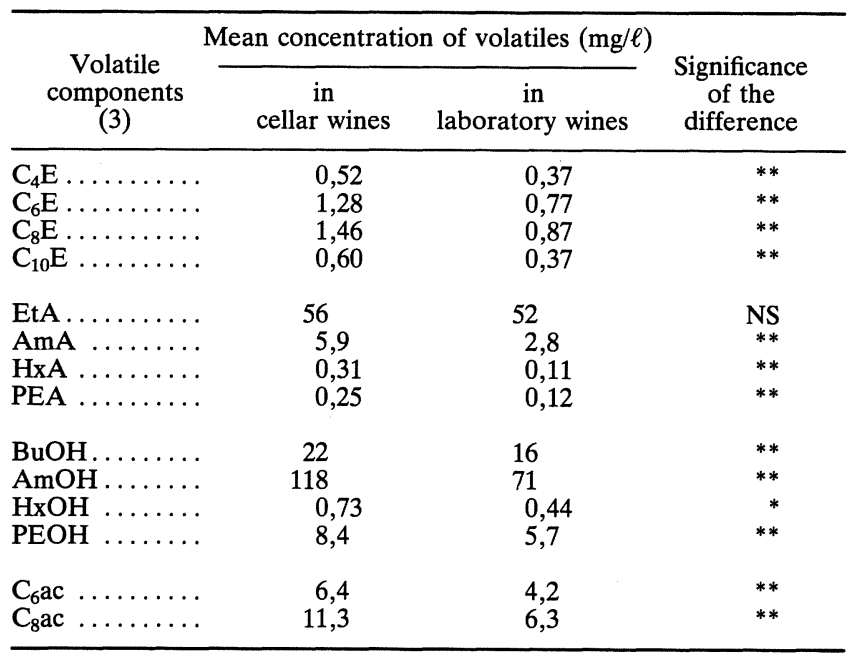

${ }^{1}$ Two groups of 12 wines each were used (filtered and de-aerated juice with ergosterol addition).

${ }^{2}$ Cellar scale $65 \ell$; laboratory scale $0,4 \ell$.

${ }^{3}$ Abbreviations as in Tables 4 and 5.

*Significant at $\mathrm{P} \leqslant 0,05$.

**Highly significant at $P \leqslant 0,01$.

NS Not significant.

\section{SUMMARY AND CONCLUSIONS}

According to South-African cellar experience the finest white wines are prepared from clear grape juice under strictly anaerobic conditions. After settling with bentonite, grape juice generally retains a finely dispersed residual turbidity. This turbidity in the juice proved to be responsible for off-flavours and low wine scores in a considerable percentage of wines made from settled juice. However, with perfectly clear EK-filtered juice other problems arise. Complete de-aeration of the juice always caused lagging and incomplete fermentation. On
TABLE 9

The effect of ammonium-nitrogen addition to filtered juice on the concentrations of volatiles in wines

\begin{tabular}{|c|c|c|c|}
\hline & \multicolumn{2}{|c|}{$\begin{array}{l}\text { Amino-N concentration of juices } \\
(\mathrm{mg} / \ell)\end{array}$} & \multirow[t]{2}{*}{$\begin{array}{l}\text { Significance } \\
\text { of difference }\end{array}$} \\
\hline & 105 & 300 & \\
\hline $\begin{array}{c}\text { Volatile } \\
\text { components (1) }\end{array}$ & \multicolumn{2}{|c|}{$\begin{array}{l}\text { Mean concentration of volatiles } \\
(\mathrm{mg} / \ell)\end{array}$} & \\
\hline $\mathrm{C}_{4} \mathrm{E} \ldots \ldots \ldots$ & 0,27 & 0,27 & NS \\
\hline $\mathrm{C}_{6} \mathrm{E} \ldots \ldots \ldots$ & 0,63 & 0,62 & NS \\
\hline $\mathrm{C}_{8} \mathrm{E} \ldots \ldots \ldots$ & 0,79 & 0,73 & $*$ \\
\hline $\mathrm{C}_{10} \mathrm{E} \ldots \ldots \ldots$ & 0,35 & 0,31 & NS \\
\hline EtA. & 33 & 35 & NS \\
\hline AmA $\ldots \ldots \ldots$ & 1,55 & 1,45 & NS \\
\hline $\mathrm{HxA} \ldots \ldots \ldots$ & 0,08 & 0,08 & NS \\
\hline PEA $\ldots \ldots \ldots$ & 0,09 & 0,06 & * \\
\hline $\mathrm{BuOH} .$. & 15 & 15,5 & NS \\
\hline $\mathrm{AmOH}$ & 77 & 65 & $*$ \\
\hline $\mathrm{HxOH} \ldots \ldots \ldots$ & 0,52 & 0,53 & NS \\
\hline PEOH $\ldots \ldots \ldots$ & 7,4 & 5,3 & ** \\
\hline
\end{tabular}

${ }^{1}$ Abbreviations as in Table 4.

* Significant at $\mathrm{P} \leqslant 0,05$.

**Highly significant at $P \leqslant 0,01$.

NS Not significant. 
lagging fermentation may be expected. Using EK-filtered and de-aerated juice as basic material, it is possible to determine the demands of yeast for stimulating agents, viz. oxygen, finely dispersed grape material or ergosterol. This also allows for a basis for investigating the effects of these agents on aroma formation. EK-filtrates and filtrates through No. 3 sheets appear identically clear, yet the No. 3 filtrates ferment more actively than the EKfiltrates, indicating that a small amount of emulsified grape steroids has a big effect on fermentation. Very small quantities of oxygen introduced during different stages of fermentation (10-30 $\mathrm{mg} \mathrm{O}_{2} / \ell /$ day) have a similar effect on fermentation. In practice, too slow fermentations should be stimulated in an early stage, viz. at the first indication of lagging. In later phases of fermentation the results are less successful. Nevertheless, it has often been possible to reactivate lagging fermentations in EKfiltrates even at the 45th day after inoculation by an admixture of $25 \%$ by volume of settled juice. The application of air, especially in a later stage of fermentation, could easily cause oxidation and should therefore be omitted.

Because the highest wine scores were obtained with fermentations of EK-filtered juices stimulated by ergosterol addition, a thorough investigation of the natural cell proliferation promoting steroids, and also of the very active emulsifying agents in the grape, could have considerable practical implications.

With regard to wine aroma, it should be kept in mind that, even exclusive of ethanol and acetic acid, $90 \%$ $(\mathrm{m} / \mathrm{m})$ of wine volatiles consists of fourteen components, belonging to four chemical classifications, viz. higher alcohols, their acetates, fatty acids and their ethyl esters. The production of ethyl esters is relatively independent of the fermentation method. As was already indicated in earlier publications, the concentrations of the ethyl esters of octanoic and decanoic acids in the wines correlate with the sugar content and thus with the maturity of the grapes.

In the present study it has been shown that the formation of higher alcohols is nearly entirely affected by two factors, namely juice turbidity in combination with fermentation temperature. The results of numerous laboratory experiments with filtered juice indicated that the concentrations of the three main higher alcohols, i-butanol, i-amyl alcohol and 2-phenyl ethanol, amounted to a rather constant total of $90 \mathrm{mg} / \ell$ at $13^{\circ}, 15^{\circ}$ as well as at $25{ }^{\circ} \mathrm{C}$. In wines from settled juice fermented at $13{ }^{\circ} \mathrm{C}$ and $25^{\circ} \mathrm{C}$, the total higher alcohol concentrations on the other hand amounted to 170 and $375 \mathrm{mg} / \ell$ respectively. The temperature dependency of higher alcohol formation can, therefore, be fully ascribed to the residual turbidity in the juice. The concentration of acetates in wines varies over a wide range, and i-amyl acetate for instance, is found in concentrations ranging from 0,8 to $15 \mathrm{mg} / \ell$. The acetates, therefore, are sensitive indicators for reproducibility in wine making. Acetate production was highly significantly affected by the presence of ergosterol in the juice.

Slight aeration in the second phase of fermentation resulted in a partial oxidation of ethyl decanoate to ethyl dec-9-enoate. Virtually no other effects of aeration on the composition of the fermentation aroma were observed.

\section{LITERATURE CITED}

ARIES, V. \& KIRSOP, B. H., 1977. Sterol synthesis in relation to growth and fermentation by brewing yeasts inoculated at different concentrations. J. Inst. Brew. 83, 220-223.

ARIES, V. \& KIRSOP, B. H., 1978. Sterol biosynthesis by strains of saccharomyces cerevisiae in the presence and absence of dissolved oxygen. J. Inst. Brew. 84, 118-122.

ASMUNDO, C. N. \& ZAMORANI, A., 1976. Die Bildung höherer Alkohole während der Gärung der Moste bei verschiedener Temperatur. Vignevini (Bologna) 3, (3-4), 17-19. Vitis Abstr. 15, 206.

BERTRAND, A., MARLY-BRUGEROLLE, C. \& SARRE, C., 1978. Influence du debourbage des mouts et du sulfitage sur les teneurs en substances volatiles des vins et des eaux-de-vie. I. Etude des vins. Connaiss. Vigne Vin 12, $35-48$.

CROWELL, E. A. \& GUYMON, J. F., 1963. Influence of aeration and suspended material on higher alcohols, acetoin and diacetyl during fermentation. Am. J. Enol. Vitic. 14, 214-222.

DAVID, M. H. \& KIRSOP, B. H., 1973. Yeast growth in relation to the dissolved oxygen and sterol content of wort. J. Inst. Brew. 79, 20-25.

DITTRICH, H. H., 1978. Neue Ergebnisse zur Böckserbildung. Weinwirtsch. (Neustadt/Wstr.) 114, 760-762.

GROAT, M. \& OUGH, C. S., 1978. Effects of insoluble solids added to clarified musts on fermentation rate, wine composition and wine quality. Am. J. Enol. Vitic. 29, 112-119.

HOUTMAN, A. C., MARAIS, J. \& DU PLESSIS, C. S., $1980 \mathrm{a}$. Factors affecting the reproducibility of fermentation of grape juice and of the aroma composition of wines. I. Grape maturity, sugar, inoculum concentration, aeration, juice turbidity and ergosterol. Vitis 19, 37-54.

HOUTMAN, A. C., MARAIS, J. \& DU PLESSIS, C. S., 1980b. The possibilities of applying present-day knowledge of wine aroma components. Influence of several juice factors on fermentation rate and ester production during fermentation. S. Afr. J. Enol. Vitic. 1, 27-34.

KILLIAN, E. \& OUGH, C. S., 1979. Fermentation estersformation and retention as affected by fermentation temperature. Am. J. Enol. Vitic. 30, 301-305.

KIRSOP, B. H., 1978. Pitching rate. Brewer's Digest, 28-32.

LAFON-LAFOURCADE, S. \& RIBÉREAU-GAYON, P., 1979. Quelques observations sur les problèmes microbiologiques de la vinification en blanc. Connaiss. Vigne Vin 13, 51-76.

LARUE, F., LAFON-LAFOURCADE, S. \& RIBÉREAUGAYON, P., 1978. Relations entre la teneur cellulaire en stérols et l'activité fermentaire des levures dans le moût de raisin. Rôle fonctionnel des steroïdes. Compt. Rend Acad. Sc. , 287D, 1445-1448.

MARAIS, J. \& HOUTMAN, A. C., 1979. Quantitative gas chromatographic determination of specific ester and higher alcohols in wine using freon extraction. Am. J. Enol. Vitic. 30, 250-252.

MARAIS, J., VAN ROOYEN, P. C. \& DU PLESSIS, C. S., 1981. Classification of white cultivar wines by origin using volatile aroma components. S. Afr. J. Enol. Vitic. 2, 45-49.

MÜLLER-SPÄTH, H., 1977. Neueste Erkenntnisse über den Sauerstoffeinfluss bei der Weinbereitung-aus der Sicht der Praxis. Weinwirtschaft 113, 144-157.

MÜLLER-SPÄTH, H., LOESCHER, TH. \& SCHÄFER, G., 1977. Einfluss des Sauerstoffs bei der Weinbereitung-von der Traube bis zur Flaschenfüllung. Deutsche Weinbau 32, 384-392.

NORDSTRÖM, K., 1963. Formation of ethyl acetate in fermentation with brewer's yeast. IV. Metabolism of acetylcoenzyme-A. J. Inst. Brew. 69, 142-153. 
NORDSTRÖM, K., 1966. Formation of esters from lower fatty acids by various yeast species. J. Inst. Brew. 72, 38-40.

PERSCHEID, M. \& ZÜRN, F., 1976. Über die Bedeutung des Sauerstoffs bei der Weinbereitung. Wein-Wiss. 31, 287 -300 .

RIBÉREAU-GAYON, P., LAFON-LAFOURCADE，S. \& BERTRAND, A., 1975. Le debourbage des mouts de vendange blanche. Connaiss. Vigne Vin 9, 117-139.

RIBÉREAU-GAYON, P., SUDRAUD, P. \& LAFONLAFOURCADE, S., 1978. Incidence des techniques de vinification sur la constitution des vins blancs. Connaiss. Vigne Vin 12, 49-56.

SAPIS-DOMERCQ, S. \& PEYNAUD, E. 1973. Influence de divers procédés de thermovinification sur la microflore levurienne. Connaiss. Vigne Vin 7, 189-201.

SINGLETON, V. L., SIEBERHAGEN, H. A., DE WET, P. \& VAN WYK, C. J., 1975. Composition and sensory qualities of wines prepared from white grapes by fermentation with and without grape solids. Am.J. Enol. Vitic. 26, $62-69$.

VOS, P. J. A. \& GRAY, R. S., 1979. The origin and control of hydrogen sulfide during fermentation of grape must. Am.J. Enol. Vitic. 30, 187-197.

WENZEL, K. \& DITTRICH, H. H., 1978. Zur Beeinflussung der Schwefelwasserstoff-Bildung der Hefe durch Trub, Stickstoffgehalt, molekularen Schwefel und Kupfer bei der Vergärung von Traubenmost. Wein-Wiss. 33, 200-214.

WILLIAMS, J. T., OUGH, C. S. \& BERG, H. W., 1978. White wine composition and quality as influenced by method of must clarification. Am. J. Enol. Vitic. 29, 92-96.

WUCHERPFENNING, K. \& BRETTHAUER, G., 1970. Über die Bildung von flüchtigen Aromastoffen in Traubenwein in Abhängigkeit von der Mostvorbehandlung sowie von der verwendeten Heferasse. Mitt. Klosterneuburg 20, 36-46. 